\title{
Characteristics Predicting a High Caregiver Burden in Patients with Vascular Cognitive Impairment: Using the Apriori Algorithm to Delineate the Caring Scenario
}

Kai-Ming Jhang ${ }^{1, *}$

Wen-Fu Wang ${ }^{1,2, *}$

Hsin-Fang Chang ${ }^{3, *}$

Ming-Che Chang ${ }^{4}$

Hsin-Hung Wu $\mathbb{D}^{3,5,6}$

'Department of Neurology, Changhua Christian Hospital, Changhua, Taiwan;

${ }^{2}$ Department of Holistic Wellness, Ming Dao University, Changhua, Taiwan;

${ }^{3}$ Department of Business Administration, National Changhua University of Education, Changhua, Taiwan; ${ }^{4}$ Department of Nuclear Medicine, Changhua Christian Hospital, Changhua, Taiwan; ${ }^{5}$ Department of M-Commerce and Multimedia Applications, Asia University, Taichung City, Taiwan; ${ }^{6}$ Faculty of Education, State University of Malang, Malang, East Java, Indonesia

*These authors contributed equally to this work

This article was published in the following Dove Press journal:

Risk Management and Healthcare Policy

Purpose: The aim of this study was to elucidate the factors and caring scenarios associated with a moderate to severe care burden in the caregivers of patients with vascular cognitive impairment (VCI).

Patients and Methods: This cross-sectional study included 158 patients with VCI and their caregivers who were managed by the dementia collaborative care team at Changhua Christian Hospital, Taiwan. Gender, age, clinical dementia rating, walking ability, behavioral symptoms, and psychological symptoms were the variables from the patients with VCI. Age, marital status, relation to the VCI patient, education, employment status, help of key activities, type of primary care, frequency of care, ZBI (Zarit burden interview) caregiving burden, and caregiver's mood were the evaluated variables for the caregivers. The Apriori algorithm was used to identify the attributes that resulted in different caregiving burdens from a comprehensive viewpoint of both VCI patients and their caregivers.

Results: A total of 1193 rules were identified with 1134 rules belonging to caregivers with a mild to moderate burden and 59 rules belonging to caregivers with a moderate to severe burden. Seven general rules were created based on a summary of these 59 rules. The results showed that an employed female caregiver who was taking care of her husband alone for $\geq 6$ days per week, and who was helping with all key activities was likely to experience a moderate to severe burden when the patient had VCI. Moreover, if the caregiver had a relatively low education level and expressed an abnormal mood during the assessment, this increased the likelihood of the caregiver having a moderate to severe burden.

Conclusion: The caregiver's gender, relation to the care recipient, education level, mood status, employment status, and care loading were associated with a higher burden of care for caregivers of patients with VCI. Therefore, a dementia care team should provide personalized training for caregivers about the disease, care skills for specific behaviors and psychological symptoms of dementia (BPSD), and strategies to cope with their own feelings. Caregivers should also be referred to appropriate social resources, such as support groups or respite care.

Keywords: vascular cognitive impairment, dementia, caregivers, caregiving burden, Zarit burden interview, caring scenario, Apriori algorithm

\section{Introduction}

Dementia, an illness strongly associated with aging, has become one of the greatest global challenges for health and social care. ${ }^{1}$ Progressive cognitive and functional decline and associated neuropsychiatric symptoms place a considerable burden on

Correspondence: Hsin-Hung Wu Email hhwu@cc.ncue.edu.tw
Risk Management and Healthcare Policy 202I:|4 |335-135| 
caregivers. $^{2}$ Informal caregivers reported higher levels of depression and anxiety, ${ }^{3,4}$ engagement in fewer protective health behaviors, and were at an increased risk of medical illness $^{5}$ and mortality. ${ }^{6}$ Caregivers can vary considerably in their level of burden, indicating there is a subjective measure to the physical, economic, and psychosocial strain of caregiving; this is considered to be a product of dynamic interactions among caregiver resources, vulnerabilities, and care demands. ${ }^{7}$

Previous systematic reviews found that the predictors of a high burden for caregivers of people with dementia included increased behavioral impairment (especially disruptive behaviors) and decline in functional status in the patient, the caregiver's socio-economic factors (such as being a female spouse) and their psychological health. ${ }^{8-10}$ By using the Apriori algorithm, our previous studies delineated caring scenarios associated with the high caregiver burden for dementia. ${ }^{11,12}$ Unlike traditional statistical tools which only declare specific factors, the Apriori algorithm, a data mining method, reveals statistical correlations from a multidimensional viewpoint when each attribute is viewed as a dimension by establishing threshold values of support and confidence. ${ }^{13}$

One of our previous studies found that when spouses were the only ones taking care of male 75-79-year-old with dementia who do not need help with their daily living activities (still walk independently) for $\geq 6$ days per week, the caregiver would experience a high level of burden. ${ }^{11}$ In addition, when one of the following scenarios was identified, a moderate to severe caregiving burden were delineated: ${ }^{12}$ caregivers expressed any one of several moods (emotional liability, depressive, or anxious) and patients can still walk independently; caregivers who were relatives but not the spouses or children aged less than 50-year-old who have married, and the patients had mild dementia; employed caregivers who needed to take care of patients' physical conditions and/or activities of daily living (ADL) or were navigating in and through the healthcare system or rehabilitation.

Vascular cognitive impairment (VCI) refers to all forms of cognitive disorders associated with cerebrovascular disease, encompassing the full range of cognitive deficits from mild cognitive impairment to dementia. ${ }^{14}$ Vascular dementia (VaD) is now recognized as the second most common form of dementia after Alzheimer's disease (AD). The percentages of $\mathrm{AD}$ and $\mathrm{VaD}$ in the Chinese population were reported to be $63.3 \%$ and $28.5 \%$, respectively. ${ }^{15} \mathrm{VCI}$ is more prevalent in males, and patients often have more gait disturbances, focal neurological deficits, executive dysfunctions, and different neuropsychological profiles (less agitation and aggression but more apathy) when compared with patients with AD. ${ }^{16-18}$

Limited literature discussing the burden for caregivers of VCI patients has been found. D'Onofrio et $\mathrm{al}^{19}$ found that $\mathrm{AD}$ caregivers had a higher burden level compared with $\mathrm{VaD}$ caregivers, and this appeared to be associated with there being more female caregivers who administered care for a longer length of time for $\mathrm{AD}$ patients. Vetter et $\mathrm{al}^{20}$ reported that $\mathrm{VaD}$ patients imposed a greater caregiver burden in the early stage compared with $\mathrm{AD}$ patients, but that the relationship underwent a reversal in severe disease stages, where the relatives of AD patients experienced more adverse burden compared with those of VaD patients. Conversely, Yeager et $\mathrm{al}^{21}$ revealed that the primary dementia diagnosis ( $\mathrm{VaD}$ or $\mathrm{AD}$ ) was not associated with the caregiver burden.

Patients with VCI have different characteristics, clinical presentations, and functional and cognitive trajectories from other neurodegenerative dementia types. ${ }^{14}$ When compared with all dementia subtypes, care for the mood of the caregiver was an important and frequent care need for the caregivers of male patients with VCI. ${ }^{22,23}$ Patients with VCI may have specific factors associated with the caregiver burden other than those observed in neurodegenerative dementia. More importantly, identifying caregivers who are at a high risk of increased levels of burden in a particular patient population is an important strategy for targeting clinical interventions. Therefore, the aim of the current study was to use the Apriori algorithm to elucidate the factors and caring scenarios, which are associated with moderate to severe burden levels in caregivers of VCI patients.

\section{Patients and Methods}

Patients diagnosed with mild cognitive impairment or dementia at the memory clinic of Changhua Christian Hospital between January 2014 and August 2019 were enrolled in the current study. The clinical trial was approved by the Institutional Review Board of Changhua Christian Hospital (CCH IRB 160165). The need for informed consent was waived by the Institutional Review Board of Changhua Christian Hospital because of the retrospective study design. All data were recorded in the electronic medical chart with the highest confidentiality and compliance with the 
Declaration of Helsinki. Initially, there were 1662 patients but only 308 had VCI. In addition, 67 patients had incomplete data and 83 did not have burden scores for the caregivers'. Therefore, the final number of patients with VCI included for analysis within the current study was 158. The International Society for Vascular Behavioral and Cognitive disorders (VASCOG) criteria were used for the diagnosis of $\mathrm{VCI}^{24}$ To better reflect the conditions for both VCI patients and their caregivers in a timely basis, the most recent diagnosis and interview data were used.
In the present study, the variables assessed for VCI patients were gender, age, clinical dementia rating (CDR), walking ability, mood symptoms, behavioral symptoms, and psychological symptoms (Table 1), whereas the variables assessed for their caregivers included age, marital status, relation to the VCI patient, education, employment, help of key activities, type of primary care, frequency of care, ZBI caregiving burden, and caregiver's mood (Table 2). The presence of behaviors and psychological symptoms of dementia (BPSD) was evaluated by psychologists or trained nursing case

Table I VCl Patient Information

\begin{tabular}{|c|c|c|c|c|}
\hline \multicolumn{2}{|l|}{ Variables } & \multirow{3}{*}{$\begin{array}{r}\text { Frequency } \\
74 \\
84\end{array}$} & \multirow{3}{*}{$\begin{array}{r}\text { Percentage } \\
46.8 \\
53.2\end{array}$} & Data Type \\
\hline Gender of the care recipient & Male & & & I \\
\hline & Female & & & 0 \\
\hline \multirow[t]{4}{*}{ Age of the care recipient } & $<65$ years old & 13 & 8.2 & I \\
\hline & $65-74$ years old & 26 & 16.5 & 2 \\
\hline & $75-84$ years old & 66 & 41.8 & 3 \\
\hline & $\geq 85$ years old & 53 & 33.5 & 4 \\
\hline \multirow[t]{4}{*}{ CDR of the care recipient } & Very mild dementia & 44 & 27.8 & I \\
\hline & Mild dementia & 64 & 40.5 & 2 \\
\hline & Moderate dementia & 32 & 20.3 & 3 \\
\hline & Severe dementia & 18 & 11.4 & 4 \\
\hline \multirow{4}{*}{$\begin{array}{l}\text { Walking ability of the care } \\
\text { recipient }\end{array}$} & Independent & 63 & 39.9 & 0 \\
\hline & Walker or cane & 55 & 34.8 & I \\
\hline & Wheelchair & 37 & 23.4 & 2 \\
\hline & Bedridden & 3 & 1.9 & 3 \\
\hline \multirow[t]{6}{*}{ Mood symptoms } & Dysphoria & 26 & 16.5 & \multirow{6}{*}{$\begin{array}{l}\mathrm{I}: \text { with the symptom; and } 0: \text { without the } \\
\text { symptom }\end{array}$} \\
\hline & Depression & 15 & 9.5 & \\
\hline & Anxiety & 10 & 6.3 & \\
\hline & Pathological crying or laughing & 12 & 7.6 & \\
\hline & Apathy & 8 & 5.1 & \\
\hline & Euphoria & 0 & 0 & \\
\hline \multirow{10}{*}{$\begin{array}{l}\text { Behavioral symptoms (multiple } \\
\text { choice) }\end{array}$} & Agitation & 7 & 4.4 & \multirow{13}{*}{$\begin{array}{l}\text { I: with the symptom; and } 0 \text { : without the } \\
\text { symptom }\end{array}$} \\
\hline & Akathisia & 1 & 0.6 & \\
\hline & Wandering & 0 & 0 & \\
\hline & Curse & 6 & 3.8 & \\
\hline & Shadowing & 1 & 0.6 & \\
\hline & Aggression (verbal/body) & 9 & 5.7 & \\
\hline & Disinhibition & 3 & 1.9 & \\
\hline & Akinesia & 6 & 3.8 & \\
\hline & Nighttime behavior & 13 & 8.2 & \\
\hline & $\begin{array}{l}\text { Aberrant motor behavior } \\
\text { (stereotype) }\end{array}$ & 3 & 1.9 & \\
\hline \multirow{3}{*}{$\begin{array}{l}\text { Psychological symptoms (multiple } \\
\text { choice) }\end{array}$} & Delusion & 29 & 18.4 & \\
\hline & Hallucination & 17 & 10.8 & \\
\hline & Misidentification & 13 & 8.2 & \\
\hline
\end{tabular}

Abbreviation: $C D R$, clinical dementia rating. 
Table 2 VCl Patient Caregiver Information

\begin{tabular}{|c|c|c|c|c|}
\hline \multicolumn{2}{|l|}{ Variables } & \multirow{2}{*}{$\begin{array}{r}\text { Frequency } \\
36\end{array}$} & \multirow{2}{*}{$\begin{array}{r}\text { Percentage } \\
22.8\end{array}$} & Data Type \\
\hline Age of the caregiver & $<50$ years old & & & I \\
\hline & $50-59$ years old & 54 & 34.2 & 2 \\
\hline & 60-69 years old & 37 & 23.4 & 3 \\
\hline & $\geq 70$ years old & 31 & 19.6 & 4 \\
\hline \multirow{7}{*}{$\begin{array}{l}\text { Caregiver's marital } \\
\text { status }\end{array}$} & Married & 135 & 85.5 & I \\
\hline & Divorce & 3 & 1.9 & 2 \\
\hline & Widow/widower & 4 & 2.5 & 3 \\
\hline & Separate & 0 & 0 & 4 \\
\hline & Cohabitation & I & 0.6 & 5 \\
\hline & Single & 15 & 9.5 & 6 \\
\hline & Unknown & 0 & 0 & 7 \\
\hline \multirow{10}{*}{$\begin{array}{l}\text { Relation to the } \mathrm{VCl} \\
\text { patient }\end{array}$} & Himself/herself & 0 & 0 & 0 \\
\hline & Spouse & 47 & 29.8 & I \\
\hline & Partner & I & 0.6 & 2 \\
\hline & Child & 82 & 51.9 & 3 \\
\hline & Brothers/sisters & 2 & 1.3 & 4 \\
\hline & Other relatives & 24 & 15.2 & 5 \\
\hline & Male friends or neighbors & I & 0.6 & 6 \\
\hline & Female friends or neighbors & 0 & 0 & 7 \\
\hline & Male foreign worker or household & I & 0.6 & 8 \\
\hline & Female foreign worker or household & 0 & 0 & 9 \\
\hline \multirow[t]{5}{*}{ Caregiver's education } & Elementary school or below (0-6 years) & 38 & 24.1 & I \\
\hline & Junior high school (7-9 years) & 19 & 12.0 & 2 \\
\hline & Senior high school (10-12 years) & 44 & 27.8 & 3 \\
\hline & College and above ( $\geq 13$ years) & 53 & 33.6 & 4 \\
\hline & Unknown & 4 & 2.5 & 5 \\
\hline \multirow[t]{2}{*}{ Employment } & Unemployed or retired & 77 & 48.7 & 0 \\
\hline & Employed & 81 & 51.3 & I \\
\hline \multirow[t]{3}{*}{$\begin{array}{l}\text { Help of key activities } \\
\text { (multiple choice) }\end{array}$} & $\begin{array}{l}\text { Physical condition and/or activities of } \\
\text { daily living }\end{array}$ & 112 & 70.9 & $\begin{array}{l}\text { I: with the help of a key activity; and } 0 \text { : } \\
\text { without the help of a key activity }\end{array}$ \\
\hline & $\begin{array}{l}\text { Navigating in and through the healthcare } \\
\text { system or rehabilitation }\end{array}$ & 148 & 93.7 & \\
\hline & Accompany & 154 & 97.5 & \\
\hline \multirow[t]{5}{*}{ Type of primary care } & Sole caregiver & 56 & 35.4 & I \\
\hline & $\begin{array}{l}\text { Shared caregiving by a caregiver and } \\
\text { a foreign worker/household }\end{array}$ & 52 & 32.9 & 2 \\
\hline & Shared caregiving by different relatives & 3 & 1.9 & 3 \\
\hline & Caregiving by a foreign worker & 32 & 20.3 & 4 \\
\hline & Other & 15 & 9.5 & 5 \\
\hline \multirow[t]{3}{*}{ Frequency of care } & I-2 days per week & 9 & 5.7 & I \\
\hline & $3-5$ days per week & 12 & 7.6 & 2 \\
\hline & $\geq 6$ days per week & 137 & 86.7 & 3 \\
\hline \multirow[t]{4}{*}{ ZBI caregiving burden } & Little or no burden & 61 & 38.6 & $\begin{array}{l}\text { I: applied to a particular burden; and } 0 \text { : } \\
\text { otherwise }\end{array}$ \\
\hline & Mild to moderate burden & 68 & 43.1 & \\
\hline & Moderate to severe burden & 22 & 13.9 & \\
\hline & Severe burden & 7 & 4.4 & \\
\hline
\end{tabular}

(Continued) 
Table 2 (Continued).

\begin{tabular}{|l|l|r|r|l|}
\hline \multicolumn{2}{|l|}{ Variables } & Frequency & Percentage & Data Type \\
\hline Caregiver's mood & Helplessness & 22 & 13.9 & I: with the mood; and 0: without the mood \\
(multiple choice) & Loneliness & 4 & 2.5 & \\
& Depression & 9 & 5.7 & \\
& Anxiety & 18 & 11.4 & \\
& Frustration & 10 & 6.3 & \\
& Nervousness & 32 & 20.3 & \\
& Anger & 35 & 22.2 & \\
& Sadness & 8 & 5.1 & \\
& Emotional liability & 11 & 7.0 & \\
& Troublesome & 21 & 13.3 & \\
& Hopelessness & 22 & 13.9 & \\
\hline
\end{tabular}

managers. Most of the BPSD listed in the neuropsychiatric inventory were recorded. Other abnormal behaviors frequently observed in dementia subjects including wandering, pathological crying or laughing, cursing others, akathisia, and akinesia were also noted by trained nursing case managers.

Caregiver's depression was defined by the Center for Epidemiologic Studies Depression Scale (CES-D) as a score of $\geq 16$ points. $^{25}$ The caregiver's mood was evaluated using the Chinese Health Questionnaire (CHQ-12) and the Brief Symptom Rating Scale (BSRS-5). ${ }^{26,27}$ Both questionnaires are short, self-administered screening tools for general mental health. Caregivers who responded to the BSRS-5 saying they were feeling worried and nervous, easily felt angry, felt low or sad, or felt that it was difficult to catch up with others were scored as nervousness, anger, sadness, or frustration, respectively (Table 2). Caregivers who answered abnormal responses to the following questions in the CHQ$12^{26}$ were recorded as having the mood listed in the corresponding bracket: feeling unable to get along with families and friends (loneliness); loss of confidence or a feeling of helplessness (helplessness); feeling tension or anxious (anxiety); feeling discourage or troublesome about family (troublesome); and feeling hopeless in life (hopelessness). Questions about somatization (such as feeling paresthesia, palpitation, chest tightness, or insomnia) in the CHQ-12 $2^{26}$ were not used in the present study. Emotional liability was selected if rapid, exaggerated changes in the caregiver's mood were noted by the collaborative team members. The care recipient's mood, behavioral and psychological symptoms of the VCI patients, help of key activities, and the caregiver's mood used a two-point scale to record the data
(1 if the symptom/activity/mood was applied; 0 if not). In addition, the ZBI caregiving burden, as assessed by the Zarit burden interview, was classified into four categories based on numerical scores from 0 to 88 : little or no burden (0-20 points), mild to moderate burden ( $21-40$ points), moderate to severe burden (41-60 points), and severe burden (61-88 points). When a caregiving burden falls in a particular category, a value of 1 is assigned, and a value of zero is given to the other three categories.

A majority of the VCI patients in Table 1 were aged 75 years or older $(75.3 \%)$ and had mild dementia $(\mathrm{CDR}=1$, $40.5 \%$ ). The number of female patients was slightly higher than the number of male patients. In addition, most of the VCI patients could either walk independently (39.9\%) or use a walker or cane $(34.8 \%)$. In contrast to the VCI patients, the age of the caregivers was uniformly distributed across four age groups, and the majority of caregivers were married $(85.5 \%)$ with an education of either senior high school $(27.8 \%)$ or college and above $(33.6 \%)$. Frequency of care $\geq 6$ days per week ( $86.7 \%$ ), and children (51.9\%) and spouses (29.8\%) were the major factors to consider when evaluating the care of VCI patients. Additionally, the caregiving burden mainly fell into either the mild to moderate burden $(43.1 \%)$ or little or no burden (38.6\%) categories.

The aim of this study was to identify which attributes could result in different caregiving burdens from a comprehensive viewpoint of both VCI patients and their caregivers. The Apriori algorithm was applied to reveal statistical correlations from a multidimensional viewpoint when each attribute was viewed as a dimension by setting up support, confidence, and lift. ${ }^{12,13,22,23}$ Yan et al $^{11}$ reported that the Apriori algorithm 
was very effective for identifying caregiving burden levels when patients with dementia and their caregivers were taken into account simultaneously. Therefore, the Apriori algorithm was employed in this study. The definitions of support, confidence, and lift are as follows. ${ }^{11,22,23}$ The support of an association rule $\mathrm{A} \Rightarrow \mathrm{B}$ is used to compute the percentage of transactions containing both $\mathrm{A}$ and $\mathrm{B}$ in the database, as shown in Equation (1).

$$
\begin{aligned}
& \text { Support }(\mathrm{A} \Rightarrow \mathrm{B})=P(A \cap B) \\
& =\frac{\text { number of transactions containing both } \mathrm{A} \text { and } \mathrm{B}}{\text { total number of transactions }}
\end{aligned}
$$

The confidence of the association rule $\mathrm{A} \Rightarrow \mathrm{B}$ is used to evaluate the accuracy of the rule by calculating the percentage of transactions containing A and also containing $\mathrm{B}$ simultaneously in the database as shown in Equation (2).

$$
\begin{aligned}
& \text { Confidence }(\mathrm{A} \Rightarrow \mathrm{B})=P(B \mid A)=\frac{P(A \cap B)}{P(A)} \\
& =\frac{\text { number of transactions containing both } \mathrm{A} \text { and } \mathrm{B}}{\text { number of transactions containing } \mathrm{A}}
\end{aligned}
$$

Lift is a simple correlation to measure whether $\mathrm{A}$ and $B$ are independent or dependent and correlated events as shown in Equation (3). Specifically, when a rule has a lift of one, $\mathrm{A}$ and $\mathrm{B}$ are independent and no rule will be found containing either event. When a rule has a lift larger than one, $\mathrm{A}$ and $\mathrm{B}$ are dependent and positively correlated. In practice, the decision-makers prefer rules with either high support or high confidence, and usually both. ${ }^{11}$ Moreover, strong rules are identified when certain minimum support and confidence conditions have been met.

$$
\text { Lift }(A, B)=\frac{P(A \cup B)}{P(A) P(B)}
$$

The Apriori algorithm in IBM SPSS Modeler 14.1 was used in the present study. Data type was defined by the numerical values as depicted in Tables 1 and 2 for VCI patients and their caregivers, respectively. The input variables for antecedents from Table 1 included the care recipient's gender, age, CDR, walking ability, 6 types of mood symptoms, 10 types of behavioral symptoms, and 3 types of psychological symptoms. In addition, the caregiver's age, marital status, relation to the VCI patient, education, employment, help of key activities (3 types of key activities), type of primary care, frequency of care, and 11 types of caregiver's mood from Table 2 were input variables for antecedents. The caregiver's ZBI caregiving burden (4 types) was the input variable for the consequent. Due to the heterogeneous data, the minimum support was set to $2 \%$, whereas the minimum confidence was set to $90 \%$ with a lift of $\geq 1$.

\section{Results}

There were 1193 rules generated by the Apriori algorithm with support of $2 \%$, confidence of $90 \%$, and lift $\geq 1$. Among these rules, 294 belonged to the caregivers with little or no burden, 840 belonged to the caregivers with a mild to moderate burden, and 59 belonged to the caregivers with a moderate and severe burden. The purpose of this study was to explore the caregivers' burden as much as possible, so the focus was on the moderate and severe burden. Based on these 59 rules, 7 generalized rules with similarities were summarized from Tables 3-9.

The first general rule was based on 7 trait combinations which characterized the caregiver as having a moderate to severe burden when the caregiver was an employed spouse who took care of the VCI patients alone, and who had a mood of anger. The second general rule was based on 14 trait combinations which showed that the caregiver had a moderate to severe burden when the caregiver was an employed spouse who helped the patient with one key activity (physical condition and/or activities of daily living, navigating in and through the healthcare system or rehabilitation, or accompany) and who had a mood of anger. The third general rule summarized 7 trait combinations which showed that the caregiver had a moderate to severe burden when the caregiver was employed and needed to help the patient with one key activity and had moods of anxiety and anger. The fourth general rule combined 5 trait combinations which showed that when the caregiver was an employed spouse who cared for the patient for $\geq 6$ days per week and had a mood of anger, the caregiver experienced a moderate to severe burden.

The fifth general rule combined 9 trait combinations which reported that the caregiver had a moderate to severe burden when the caregiver was employed and needed to take care of a male VCI patient for one key activity. A total of 11 trait combinations were combined to form the sixth general rule. The rule showed that when the caregiver had an education of elementary school or below, had a mood of hopelessness, and needed to care for a male patient, the caregiver felt a moderate to severe burden. Finally, the seventh general rule combined 9 trait 
Table 3 The First General Rule with 7 Similar Rules

\begin{tabular}{|c|c|c|c|c|c|}
\hline $\begin{array}{l}\text { Rule } \\
\text { No. }\end{array}$ & Antecedent & $\begin{array}{l}\text { No. of the Cases in the } \\
\text { Database }\end{array}$ & $\begin{array}{l}\text { Support } \\
\text { (\%) }\end{array}$ & $\begin{array}{l}\text { Confidence } \\
(\%)\end{array}$ & Lift \\
\hline 1 & $\begin{array}{l}\text { Employment: Employed } \\
\text { Type of primary care: Sole caregiver } \\
\text { Relation to the } \mathrm{VCl} \text { patient: Spouse } \\
\text { Caregiver's mood: Anger }\end{array}$ & 4 & 2.53 & 100 & 7.18 \\
\hline 2 & $\begin{array}{l}\text { Employment: Employed } \\
\text { Type of primary care: Sole caregiver } \\
\text { Help of key activities: Physical condition and/or activities of daily } \\
\text { living } \\
\text { Relation to the VCl patient: Spouse } \\
\text { Caregiver's mood: Anger }\end{array}$ & 4 & 2.53 & 100 & 7.18 \\
\hline 3 & $\begin{array}{l}\text { Employment: Employed } \\
\text { Type of primary care: Sole caregiver } \\
\text { Caregiver's marital status: Married } \\
\text { Relation to the VCl patient: Spouse } \\
\text { Caregiver's mood: Anger }\end{array}$ & 4 & 2.53 & 100 & 7.18 \\
\hline 4 & $\begin{array}{l}\text { Employment: Employed } \\
\text { Type of primary care: Sole caregiver } \\
\text { Frequency of care: } \geq 6 \text { days per week } \\
\text { Relation to the } \mathrm{VCl} \text { patient: Spouse } \\
\text { Caregiver's mood: Anger }\end{array}$ & 4 & 2.53 & 100 & 7.18 \\
\hline 5 & $\begin{array}{l}\text { Employment: Employed } \\
\text { Type of primary care: Sole caregiver } \\
\text { Help of key activities: Navigating in and through the healthcare } \\
\text { system or rehabilitation } \\
\text { Relation to the VCl patient: Spouse } \\
\text { Caregiver's mood: Anger }\end{array}$ & 4 & 2.53 & 100 & 7.18 \\
\hline 6 & $\begin{array}{l}\text { Employment: Employed } \\
\text { Type of primary care: Sole caregiver } \\
\text { Help of key activities: Accompany } \\
\text { Relation to the VCl patient: Spouse } \\
\text { Caregiver's mood: Anger }\end{array}$ & 4 & 2.53 & 100 & 7.18 \\
\hline 7 & $\begin{array}{l}\text { Employment: Employed } \\
\text { Type of primary care: Sole caregiver } \\
\text { Gender of the care recipient: Male } \\
\text { Relation to the VCl patient: Spouse } \\
\text { Caregiver's mood: Anger }\end{array}$ & 4 & 2.53 & 100 & 7.18 \\
\hline
\end{tabular}

combinations which showed that the caregiver had a moderate to severe burden when the caregiver was employed and needed to take care of a male patient for $\geq 6$ days per week when the caregiver had a mood of anger or hopelessness.

\section{Discussion}

The current study revealed that caregivers experienced a moderate to severe burden level when taking care of patients with VCI including employed female caregivers who were taking care of their husbands on their own for $\geq 6$ days per week, and who helped with all key activities, including physical condition, ADL and navigating in and through the healthcare system or rehabilitation and accompanying the patient. Caregivers often had a relatively low education level (0-6 years) and expressed one or more abnormal moods (nervousness, anger, and helplessness) during the assessment. 
Table 4 The Second General Rule with I4 Similar Rules

\begin{tabular}{|c|c|c|c|c|c|}
\hline $\begin{array}{l}\text { Rule } \\
\text { No. }\end{array}$ & Antecedent & $\begin{array}{l}\text { No. of the Cases } \\
\text { in the Database }\end{array}$ & $\begin{array}{l}\text { Support } \\
\text { (\%) }\end{array}$ & $\begin{array}{l}\text { Confidence } \\
(\%)\end{array}$ & Lift \\
\hline I & $\begin{array}{l}\text { Employment: Employed } \\
\text { Help of key activities: Physical condition and/or activities of daily living } \\
\text { Relation to the VCl patient: Spouse } \\
\text { Caregiver's mood: Anger }\end{array}$ & 4 & 2.53 & 100 & 7.18 \\
\hline 2 & $\begin{array}{l}\text { Employment: Employed } \\
\text { Help of key activities: Navigating in and through the healthcare system or } \\
\text { rehabilitation } \\
\text { Relation to the VCl patient: Spouse } \\
\text { Caregiver's mood: Anger }\end{array}$ & 4 & 2.53 & 100 & 7.18 \\
\hline 3 & $\begin{array}{l}\text { Employment: Employed } \\
\text { Help of key activities: Accompany } \\
\text { Relation to the VCl patient: Spouse } \\
\text { Caregiver's mood: Anger }\end{array}$ & 4 & 2.53 & 100 & 7.18 \\
\hline 4 & $\begin{array}{l}\text { Employment: Employed } \\
\text { Relation to the VCl patient: Spouse } \\
\text { Caregiver's mood: Anger }\end{array}$ & 4 & 2.53 & 100 & 7.18 \\
\hline 5 & $\begin{array}{l}\text { Employment: Employed } \\
\text { Help of key activities: Physical condition and/or activities of daily living and } \\
\text { Navigating in and through the healthcare system or rehabilitation } \\
\text { Relation to the } \mathrm{VCl} \text { patient: Spouse } \\
\text { Caregiver's mood: Anger }\end{array}$ & 4 & 2.53 & 100 & 7.18 \\
\hline 6 & $\begin{array}{l}\text { Employment: Employed } \\
\text { Help of key activities: Accompany } \\
\text { Caregiver's mood: Anger }\end{array}$ & 4 & 2.53 & 100 & 7.18 \\
\hline 7 & $\begin{array}{l}\text { Employment: Employed } \\
\text { Relation to the VCl patient: Spouse } \\
\text { Caregiver's mood: Anger }\end{array}$ & 4 & 2.53 & 100 & 7.18 \\
\hline 8 & $\begin{array}{l}\text { Employment: Employed } \\
\text { Help of key activities: Physical condition and/or activities of daily living and } \\
\text { Navigating in and through the healthcare system or rehabilitation } \\
\text { Relation to the } \mathrm{VCl} \text { patient: Spouse } \\
\text { Caregiver's mood: Anger }\end{array}$ & 4 & 2.53 & 100 & 7.18 \\
\hline 9 & $\begin{array}{l}\text { Employment: Employed } \\
\text { Help of key activities: Physical condition and/or activities of daily living and } \\
\text { Accompany }\end{array}$ & 4 & 2.53 & 100 & 7.18 \\
\hline 10 & $\begin{array}{l}\text { Employment: Employed } \\
\text { Help of key activities: Navigating in and through the healthcare system or } \\
\text { rehabilitation and Accompany } \\
\text { Relation to the VCl patient: Spouse } \\
\text { Caregiver's mood: Anger }\end{array}$ & 4 & 2.53 & 100 & 7.18 \\
\hline II & $\begin{array}{l}\text { Employment: Employed } \\
\text { Caregiver's marital status: Married } \\
\text { Relation to the VCl patient: Spouse } \\
\text { Caregiver's mood: Anger }\end{array}$ & 4 & 2.53 & 100 & 7.18 \\
\hline
\end{tabular}

(Continued) 
Table 4 (Continued).

\begin{tabular}{|c|c|c|c|c|c|}
\hline $\begin{array}{l}\text { Rule } \\
\text { No. }\end{array}$ & Antecedent & $\begin{array}{l}\text { No. of the Cases } \\
\text { in the Database }\end{array}$ & $\begin{array}{l}\text { Support } \\
(\%)\end{array}$ & $\begin{array}{l}\text { Confidence } \\
(\%)\end{array}$ & Lift \\
\hline 12 & $\begin{array}{l}\text { Employment: Employed } \\
\text { Help of key activities: Navigating in and through the healthcare system or } \\
\text { rehabilitation } \\
\text { Caregiver's marital status: Married } \\
\text { Relation to the VCl patient: Spouse } \\
\text { Caregiver's mood: Anger }\end{array}$ & 4 & 2.53 & 100 & 7.18 \\
\hline 13 & $\begin{array}{l}\text { Employment: Employed } \\
\text { Help of key activities: Accompany } \\
\text { Caregiver's marital status: Married } \\
\text { Relation to the } \mathrm{VCl} \text { patient: Spouse } \\
\text { Caregiver's mood: Anger }\end{array}$ & 4 & 2.53 & 100 & 7.18 \\
\hline 14 & $\begin{array}{l}\text { Employment: Employed } \\
\text { Help of key activities: Physical condition and/or activities of daily living } \\
\text { Caregiver's marital status: Married } \\
\text { Relation to the VCl patient: Spouse } \\
\text { Caregiver's mood: Anger }\end{array}$ & 4 & 2.53 & 100 & 7.18 \\
\hline
\end{tabular}

van den Kieboom et $\mathrm{al}^{8}$ and Xiong et $\mathrm{al}^{28}$ reported that being a female spouse is a risk factor for having a high burden when caring for people living with dementia. Care loads such as care duration and intensity (time spent on care per week) have been proven to be associated with the burden level. ${ }^{9,29}$ Our previous study also reported that a female spouse caregiver with a high care intensity experienced a moderate to high caregiving burden. ${ }^{11}$

The current study classified key care activities into three domains, including taking care of the patient's physical condition and/or ADL, navigating in and through the healthcare system, and accompanying the patient. Caregivers of VCI patients felt a moderate to severe burden when they bore the responsibility for all key activities. For caregivers of patients with all subtypes of dementia, being responsible for any two of the three key activities led to a moderate to severe caregiving burden. ${ }^{12}$ This study emphasizes the association between a high care burden and the caregiver being a female spouse with a high care load.

When compared with all dementia subtypes, ${ }^{11}$ the profile of caregivers for VCI patients showed a moderate to severe burden when the caregivers were employed and had relatively low education levels. The VCI patient population was younger than the all dementia subtypes population (age below $65 / 75$-year-old: $8.2 \% / 24.7 \%$ in this study for VCI patients versus $4.3 \% / 15 \%$ in all dementia subtypes ${ }^{11}$ ), therefore, a female spouse caregiver is more likely to still be employed. Compared with non-caregiving workers, employed caregivers of people with dementia were reported to have higher rates of absenteeism, presentism, and overall work impairment. ${ }^{30,31}$ Employment is a potential predictor for the objective burden of informal care of people with dementia. ${ }^{32}$ A higher caregiver burden is also associated with a decrease in work productivity, ${ }^{33}$ indicating that employment and the level of burden have a reciprocal interaction.

Several previous studies have evaluated education level and the burden of care for caregivers of dementia patients. Caregivers with a lower education level experienced a higher care burden and had more unsatisfied expectations in relation to the efficacy of the pharmacological treatment. ${ }^{34,35}$ Well-educated caregivers had more opportunities to contact social services and had better skills for coping with stress, which could lead to a lower subjective care burden. The present study highlighted the fact that the caregiver's employment status and education level are associated with a higher burden of care for people caring for VCI patients.

The caregiver's physical and mental health were closely associated with the burden of care when caring for people with dementia. ${ }^{8,9}$ There is plenty of previous literature that discusses the caregiver's mood and its association with the care burden. ${ }^{9,21,36,37}$ Caregivers who express anxiety, depression, or aggressiveness have been reported 
Table 5 The Third General Rule with 7 Similar Rules

\begin{tabular}{|c|c|c|c|c|c|}
\hline $\begin{array}{l}\text { Rule } \\
\text { No. }\end{array}$ & Antecedent & $\begin{array}{l}\text { No. of the Cases } \\
\text { in the Database }\end{array}$ & $\begin{array}{l}\text { Support } \\
\text { (\%) }\end{array}$ & $\begin{array}{l}\text { Confidence } \\
(\%)\end{array}$ & Lift \\
\hline 1 & $\begin{array}{l}\text { Employment: Employed } \\
\text { Caregiver's mood: Anxiety \& Anger }\end{array}$ & 4 & 2.53 & 100 & 7.18 \\
\hline 2 & $\begin{array}{l}\text { Employment: Employed } \\
\text { Caregiver's marital status: Married } \\
\text { Caregiver's mood: Anxiety \& Anger }\end{array}$ & 4 & 2.53 & 100 & 7.18 \\
\hline 3 & $\begin{array}{l}\text { Employment: Employed } \\
\text { Help of key activities: Navigating in and through the healthcare system or } \\
\text { rehabilitation } \\
\text { Caregiver's mood: Anxiety \& Anger }\end{array}$ & 4 & 2.53 & 100 & 7.18 \\
\hline 4 & $\begin{array}{l}\text { Employment: Employed } \\
\text { Help of key activities: Accompany } \\
\text { Caregiver's mood: Anxiety \& Anger }\end{array}$ & 4 & 2.53 & 100 & 7.18 \\
\hline 5 & $\begin{array}{l}\text { Employment: Employed } \\
\text { Help of key activities: Navigating in and through the healthcare system or } \\
\text { rehabilitation } \\
\text { Caregiver's marital status: Married } \\
\text { Caregiver's mood: Anxiety \& Anger }\end{array}$ & 4 & 2.53 & 100 & 7.18 \\
\hline 6 & $\begin{array}{l}\text { Employment: Employed } \\
\text { Help of key activities: Accompany } \\
\text { Caregiver's marital status: Married } \\
\text { Caregiver's mood: Anxiety \& Anger }\end{array}$ & 4 & 2.53 & 100 & 7.18 \\
\hline 7 & $\begin{array}{l}\text { Employment: Employed } \\
\text { Help of key activities: Navigating in and through the healthcare system or } \\
\text { rehabilitation and Accompany } \\
\text { Caregiver's mood: Anxiety \& Anger }\end{array}$ & 4 & 2.53 & 100 & 7.18 \\
\hline
\end{tabular}

to experience a higher burden level. ${ }^{9,21,36}$ Because there are well-established questionnaires to evaluate anxiety and depression, most studies tend to focus on the caregiver's mood using these two symptoms. However, in real clinical practice, the caregiver's mood is very complicated. In order to determine the care needs of people with dementia and their care partners, a dementia collaborative care model was established at our hospital in $2014 .^{23}$

When a diagnosis of dementia (including mild cognitive impairment) was made, the team evaluated the cognition, walking ability, and behaviors and psychological symptoms of the patient, as well as the stress, mood, and preference of the caregiver via a team-based face to face interview. The caregiver's moods such as anger, helplessness, depression, anxiety, etc. (Table 2) were assessed during the interview by team members, including physicians, psychologists, and nursing case managers using caregivers' self-administered questionnaires and clinical evaluations. The most common moods expressed by caregivers of VCI patients were anger (22.2\%) and nervousness $(20.3 \%)$, followed by helplessness and hopelessness (both 13.9\%) and feeling troublesome about the patient (13.3\%). Our previous study, which included all dementia subtypes, found that the most frequent caregiver's moods during the assessment were anger (22.6\%), feeling troublesome about the patient (19.6\%), hopelessness (18.4\%), and nervousness (17.5\%) followed by helplessness, anxiety, and frustration (all $15.8 \%)^{12}$

For the all dementia group, the following scenarios predicted a moderate to severe burden of care: a sole caregiver who expressed an anxious or depressive mood; a married caregiver with any abnormal mood who was taking care of an ambulatory independent care recipient; a caregiver who felt depressed, anxious, or liable mood who were caring for patients who could still walk independently. ${ }^{12}$ When compared with all dementia 
Table 6 The Fourth General Rule with 5 Similar Rules

\begin{tabular}{|c|c|c|c|c|c|}
\hline $\begin{array}{l}\text { Rule } \\
\text { No. }\end{array}$ & Antecedent & $\begin{array}{l}\text { No. of the Cases in the } \\
\text { Database }\end{array}$ & $\begin{array}{l}\text { Support } \\
\text { (\%) }\end{array}$ & $\begin{array}{l}\text { Confidence } \\
\text { (\%) }\end{array}$ & Lift \\
\hline I & $\begin{array}{l}\text { Employment: Employed } \\
\text { Frequency of care: } \geq 6 \text { days per week } \\
\text { Relation to the } \mathrm{VCl} \text { patient: Spouse } \\
\text { Caregiver's mood: Anger }\end{array}$ & 4 & 2.53 & 100 & 7.18 \\
\hline 2 & $\begin{array}{l}\text { Employment: Employed } \\
\text { Help of key activities: Physical condition and/or activities of daily } \\
\text { living } \\
\text { Frequency of care: } \geq 6 \text { days per week } \\
\text { Relation to the VCl patient: Spouse } \\
\text { Caregiver's mood: Anger }\end{array}$ & 4 & 2.53 & 100 & 7.18 \\
\hline 3 & $\begin{array}{l}\text { Employment: Employed } \\
\text { Caregiver's marital status: Married } \\
\text { Frequency of care: } \geq 6 \text { days per week } \\
\text { Relation to the } \mathrm{VCl} \text { patient: Spouse } \\
\text { Caregiver's mood: Anger }\end{array}$ & 4 & 2.53 & 100 & 7.18 \\
\hline 4 & $\begin{array}{l}\text { Employment: Employed } \\
\text { Help of key activities: Navigating in and through the healthcare } \\
\text { system or rehabilitation } \\
\text { Frequency of care: } \geq 6 \text { days per week } \\
\text { Relation to the } \mathrm{VCl} \text { patient: Spouse } \\
\text { Caregiver's mood: Anger }\end{array}$ & 4 & 2.53 & 100 & 7.18 \\
\hline 5 & $\begin{array}{l}\text { Employment: Employed } \\
\text { Help of key activities: Accompany } \\
\text { Frequency of care: } \geq 6 \text { days per week } \\
\text { Relation to the } \mathrm{VCl} \text { patient: Spouse } \\
\text { Caregiver's mood: Anger }\end{array}$ & 4 & 2.53 & 100 & 7.18 \\
\hline
\end{tabular}

types, ${ }^{12}$ caregivers of VCI patients had a lower frequency of abnormal moods. However, if a female caregiver of a VCI patient presented with anger, nervousness, and helplessness during the clinical assessment, she might have a higher risk of experiencing a moderate to severe care burden. Further interventions including coping strategies and referral to social resources should be introduced for this high-risk group.

Several previous studies have concluded that BPSD predicted a higher burden of care. ${ }^{8-10,21,32}$ This effect appeared to be primarily driven by disruptive behaviors (such as agitation, aggression, and disinhibition), followed by delusions and mood disturbance. ${ }^{10}$ Disruptive behaviors had an adverse impact on the emotional connection between the caregiver and the care recipient and exacerbated difficulties in caring for the patients. Our study did not connect the presence of the BPSD with a high caregiver burden. There are several possible explanations for this. First, only $4.4 \%$ and $5.7 \%$ of the study participants had agitation and aggressive behaviors, respectively. Previous studies have also found that patients with AD had a higher frequency of agitation/aggression and irritability/lability compared with patients with VaD. ${ }^{17}$ D'Onofrio et $\mathrm{al}^{19}$ found that $\mathrm{VaD}$ patients had a higher neuropsychiatric inventory score than AD patients but that caregivers of $\mathrm{VaD}$ patients had a lower burden level compared with $\mathrm{AD}$ caregivers. Because of the relatively low frequency of disruptive behaviors in the current study, BPSD might not be a strong predictive factor for assessing the caregiving burden of VCI patients. Second, $68.3 \%$ of the study population was in the early stage of the disease (including mild cognitive impairment to mild dementia). BPSD is not frequent and does not usually have a significant impact during the mild disease stage. Third, the team-based assessment evaluated whether each of the BPSD symptoms was present. However, the severity of 
Table 7 The Fifth General Rule with 9 Similar Rules

\begin{tabular}{|c|c|c|c|c|c|}
\hline $\begin{array}{l}\text { Rule } \\
\text { No. }\end{array}$ & Antecedent & $\begin{array}{l}\text { No. of the Cases } \\
\text { in the Database }\end{array}$ & $\begin{array}{l}\text { Support } \\
\text { (\%) }\end{array}$ & $\begin{array}{l}\text { Confidence } \\
(\%)\end{array}$ & Lift \\
\hline 1 & $\begin{array}{l}\text { Employment: Employed } \\
\text { Help of key activities: Navigating in and through the healthcare system or } \\
\text { rehabilitation } \\
\text { Gender of the care recipient: Male } \\
\text { Caregiver's mood: Hopelessness }\end{array}$ & 4 & 2.53 & 100 & 7.18 \\
\hline 2 & $\begin{array}{l}\text { Employment: Employed } \\
\text { Help of key activities: Accompany } \\
\text { Gender of the care recipient: Male } \\
\text { Caregiver's mood: Hopelessness }\end{array}$ & 4 & 2.53 & 100 & 7.18 \\
\hline 3 & $\begin{array}{l}\text { Employment: Employed } \\
\text { Help of key activities: Navigating in and through the healthcare system or } \\
\text { rehabilitation } \\
\text { Gender of the care recipient: Male } \\
\text { Relation to the VCl patient: Spouse } \\
\text { Caregiver's mood: Anger }\end{array}$ & 4 & 2.53 & 100 & 7.18 \\
\hline 4 & $\begin{array}{l}\text { Employment: Employed } \\
\text { Help of key activities: Accompany } \\
\text { Gender of the care recipient: Male } \\
\text { Relation to the VCl patient: Spouse } \\
\text { Caregiver's mood: Anger }\end{array}$ & 4 & 2.53 & 100 & 7.18 \\
\hline 5 & $\begin{array}{l}\text { Employment: Employed } \\
\text { Help of key activities: Physical condition and/or activities of daily living } \\
\text { Gender of the care recipient: Male } \\
\text { Relation to the VCl patient: Spouse } \\
\text { Caregiver's mood: Anger }\end{array}$ & 4 & 2.53 & 100 & 7.18 \\
\hline 6 & $\begin{array}{l}\text { Employment: Employed } \\
\text { Help of key activities: Accompany } \\
\text { Gender of the care recipient: Male } \\
\text { Caregiver's marital status: Married } \\
\text { Caregiver's mood: Hopelessness }\end{array}$ & 4 & 2.53 & 100 & 7.18 \\
\hline 7 & $\begin{array}{l}\text { Employment: Employed } \\
\text { Help of key activities: Navigating in and through the healthcare system or } \\
\text { rehabilitation } \\
\text { Gender of the care recipient: Male } \\
\text { Caregiver's marital status: Married } \\
\text { Caregiver's mood: Hopelessness }\end{array}$ & 4 & 2.53 & 100 & 7.18 \\
\hline 8 & $\begin{array}{l}\text { Employment: Employed } \\
\text { Type of primary care: Sole caregiver } \\
\text { Help of key activities: Accompany } \\
\text { Gender of the care recipient: Male } \\
\text { Age of the caregiver: } 60-69 \text { years old }\end{array}$ & 4 & 2.53 & 100 & 7.18 \\
\hline 9 & $\begin{array}{l}\text { Employment: Employed } \\
\text { Help of key activities: Navigating in and through the healthcare system or } \\
\text { rehabilitation and Accompany } \\
\text { Gender of the care recipient: Male } \\
\text { Caregiver's mood: Hopelessness }\end{array}$ & 4 & 2.53 & 100 & 7.18 \\
\hline
\end{tabular}


Table 8 The Sixth General Rule with II Similar Rules

\begin{tabular}{|c|c|c|c|c|c|}
\hline Rule No. & Antecedent & No. of the Cases in the Database & Support (\%) & Confidence (\%) & Lift \\
\hline 1 & $\begin{array}{l}\text { Caregiver's education: Elementary school or below } \\
\text { Marital status: Married } \\
\text { Gender of the care recipient: Male } \\
\text { Relation to the } \mathrm{VCl} \text { patient: Spouse } \\
\text { Caregiver's mood: Hopelessness }\end{array}$ & 4 & 2.53 & 100 & 7.18 \\
\hline 2 & $\begin{array}{l}\text { Caregiver's education: Elementary school or below } \\
\text { Marital status: Married } \\
\text { Gender of the care recipient: Male } \\
\text { Caregiver's mood: Hopelessness }\end{array}$ & 4 & 2.53 & 100 & 7.18 \\
\hline 3 & $\begin{array}{l}\text { Caregiver's education: Elementary school or below } \\
\text { Gender of the care recipient: Male } \\
\text { Caregiver's mood: Hopelessness }\end{array}$ & 4 & 2.53 & 100 & 7.18 \\
\hline 4 & $\begin{array}{l}\text { Caregiver's education: Elementary school or below } \\
\text { Gender of the care recipient: Male } \\
\text { Relation to the } \mathrm{VCl} \text { patient: Spouse } \\
\text { Caregiver's mood: Hopelessness }\end{array}$ & 4 & 2.53 & 100 & 7.18 \\
\hline 5 & $\begin{array}{l}\text { Caregiver's education: Elementary school or below } \\
\text { Help of key activities: Accompany } \\
\text { Marital status: Married } \\
\text { Gender of the care recipient: Male } \\
\text { Caregiver's mood: Hopelessness }\end{array}$ & 4 & 2.53 & 100 & 7.18 \\
\hline 6 & $\begin{array}{l}\text { Caregiver's education: Elementary school or below } \\
\text { Help of key activities: Accompany } \\
\text { Gender of the care recipient: Male } \\
\text { Relation to the VCl patient: Spouse } \\
\text { Caregiver's mood: Hopelessness }\end{array}$ & 4 & 2.53 & 100 & 7.18 \\
\hline 7 & $\begin{array}{l}\text { Caregiver's education: Elementary school or below } \\
\text { Help of key activities: Accompany } \\
\text { Gender of the care recipient: Male } \\
\text { Caregiver's mood: Hopelessness }\end{array}$ & 4 & 2.53 & 100 & 7.18 \\
\hline 8 & $\begin{array}{l}\text { Caregiver's education: Elementary school or below } \\
\text { Help of key activities: Accompany } \\
\text { Frequency of care: } \geq 6 \text { days per week } \\
\text { Gender of the care recipient: Male } \\
\text { Caregiver's mood: Hopelessness }\end{array}$ & 4 & 2.53 & 100 & 7.18 \\
\hline 9 & $\begin{array}{l}\text { Caregiver's education: Elementary school or below } \\
\text { Frequency of care: } \geq 6 \text { days per week } \\
\text { Gender of the care recipient: Male } \\
\text { Caregiver's mood: Hopelessness }\end{array}$ & 4 & 2.53 & 100 & 7.18 \\
\hline 10 & $\begin{array}{l}\text { Caregiver's education: Elementary school or below } \\
\text { Frequency of care: } \geq 6 \text { days per week } \\
\text { Gender of the care recipient: Male } \\
\text { Relation to the } \mathrm{VCl} \text { patient: Spouse } \\
\text { Caregiver's mood: Hopelessness }\end{array}$ & 4 & 2.53 & 100 & 7.18 \\
\hline
\end{tabular}

(Continued) 
Table 8 (Continued).

\begin{tabular}{|c|c|c|c|c|c|}
\hline Rule No. & Antecedent & No. of the Cases in the Database & Support (\%) & Confidence (\%) & Lift \\
\hline 11 & $\begin{array}{l}\text { Caregiver's education: Elementary school or below } \\
\text { Marital status: Married } \\
\text { Frequency of care: } \geq 6 \text { days per week } \\
\text { Gender of the care recipient: Male } \\
\text { Caregiver's mood: Hopelessness }\end{array}$ & 4 & 2.53 & 100 & 7.18 \\
\hline
\end{tabular}

Table 9 The Seventh General Rule with 9 Similar Rules

\begin{tabular}{|c|c|c|c|c|c|}
\hline $\begin{array}{l}\text { Rule } \\
\text { No. }\end{array}$ & Antecedent & $\begin{array}{l}\text { No. of the Cases } \\
\text { in the Database }\end{array}$ & $\begin{array}{l}\text { Support } \\
\text { (\%) }\end{array}$ & $\begin{array}{l}\text { Confidence } \\
(\%)\end{array}$ & Lift \\
\hline 1 & $\begin{array}{l}\text { Employment: Employed } \\
\text { Marital status: Married } \\
\text { Frequency of care: } \geq 6 \text { days per week } \\
\text { Gender of the care recipient: Male } \\
\text { Relation to the } \mathrm{VCl} \text { patient: Spouse } \\
\text { Caregiver's mood: Anger }\end{array}$ & 4 & 2.53 & 100 & 7.18 \\
\hline 2 & $\begin{array}{l}\text { Employment: Employed } \\
\text { Help of key activities: Navigating in and through the healthcare system or } \\
\text { rehabilitation and Accompany } \\
\text { Frequency of care: } \geq 6 \text { days per week } \\
\text { Gender of the care recipient: Male } \\
\text { Caregiver's mood: Hopelessness }\end{array}$ & 4 & 2.53 & 100 & 7.18 \\
\hline 3 & $\begin{array}{l}\text { Employment: Employed } \\
\text { Help of key activities: Accompany } \\
\text { Frequency of care: } \geq 6 \text { days per week } \\
\text { Gender of the care recipient: Male } \\
\text { Caregiver's mood: Hopelessness }\end{array}$ & 4 & 2.53 & 100 & 7.18 \\
\hline 4 & $\begin{array}{l}\text { Employment: Employed } \\
\text { Frequency of care: } \geq 6 \text { days per week } \\
\text { Gender of the care recipient: Male } \\
\text { Caregiver's mood: Hopelessness }\end{array}$ & 4 & 2.53 & 100 & 7.18 \\
\hline 5 & $\begin{array}{l}\text { Employment: Employed } \\
\text { Marital status: Married } \\
\text { Frequency of care: } \geq 6 \text { days per week } \\
\text { Gender of the care recipient: Male } \\
\text { Caregiver's mood: Hopelessness }\end{array}$ & 4 & 2.53 & 100 & 7.18 \\
\hline 6 & $\begin{array}{l}\text { Employment: Employed } \\
\text { Marital status: Married } \\
\text { Gender of the care recipient: Male } \\
\text { Relation to the VCl patient: Spouse } \\
\text { Caregiver's mood: Anger }\end{array}$ & 4 & 2.53 & 100 & 7.18 \\
\hline 7 & $\begin{array}{l}\text { Employment: Employed } \\
\text { Marital status: Married } \\
\text { Gender of the care recipient: Male } \\
\text { Caregiver's mood: Anger }\end{array}$ & 4 & 2.53 & 100 & 7.18 \\
\hline
\end{tabular}

(Continued) 
Table 9 (Continued).

\begin{tabular}{|c|c|c|c|c|c|}
\hline $\begin{array}{l}\text { Rule } \\
\text { No. }\end{array}$ & Antecedent & $\begin{array}{l}\text { No. of the Cases } \\
\text { in the Database }\end{array}$ & $\begin{array}{l}\text { Support } \\
\text { (\%) }\end{array}$ & $\begin{array}{l}\text { Confidence } \\
(\%)\end{array}$ & Lift \\
\hline 8 & $\begin{array}{l}\text { Employment: Employed } \\
\text { Gender of the care recipient: Male } \\
\text { Caregiver's mood: Hopelessness }\end{array}$ & 4 & 2.53 & 100 & 7.18 \\
\hline 9 & $\begin{array}{l}\text { Employment: Employed } \\
\text { Marital status: Married } \\
\text { Gender of the care recipient: Male } \\
\text { Caregiver's mood: Hopelessness }\end{array}$ & 4 & 2.53 & 100 & 7.18 \\
\hline
\end{tabular}

each of the BPSD symptoms was not scored, which might have ameliorated the association of the BPSD with the caregiver burden.

Several strategies could be applied to reduce the burden on caregivers. Caregivers, especially females, need personalized and specific training on how to understand and manage the behavior of patients with dementia and how to cope with their own feelings. ${ }^{38}$ Caregiver education programs should help caregivers to acknowledge the disease and the cognitive shift into a caregiving role as well as the development of emotional tolerance. The aim of caregiver education is to establish realistic goals, to gauge the patient's capacity, and to design opportunities that can satisfy both work and leisure. ${ }^{39}$ Providing care resources, such as daycare centers, may also reduce the caregiving burden especially if covered by health insurance. $^{40}$ People living with dementia and their care partners have been covered since the 2017 reform of home- and community-based long-term care in Taiwan. ${ }^{41}$ As of October $2019, \geq 494$ dementia community care centers have been established, which provide cognitive enhancement programs, respite care, and caregiver support groups. All of the cost for these centers is covered by the government. The dementia collaborative care team in our hospital provides personalized caregiver education and introduces care resources to the patient/caregiver partnership. $^{23}$

A strength of the present study was that it considered multiple variables, including the patient's and caregiver's characteristics, using the Apriori algorithm to determine caring scenarios associated with higher caregiver burdens. However, this study also had several limitations. First, the caregiver's moods, except for depression which was defined by the CES-D with a score $\geq 16$ points, were all defined using simple screening questions (such as feeling worried and nervous in the BSRS-5 indicated nervousness) or by clinical observations (such as emotional liability). Second, as mentioned above, the severity of the BPSD was not scored. Third, this study used a cross-sectional design, which limited the ability of the study to reveal and determine causal relationships between correlates and the caregiver burden. Fourth, potential patient factors associated with the caregiving burden such as ADL functions and patient education level ${ }^{9}$ were not included in the analysis.

\section{Conclusion}

This study concluded that the caregiver's gender, relation to the care recipient, education level, mood status, employment status, and care loading were associated with a higher burden of care for people living with VCI. A moderate to severe caregiving burden was found for cares with the following profile: employed female caregivers who had one or more abnormal moods (anger, nervousness, and helplessness) and a low education ( $\leq 6$ years) and who took care of VCI patients alone with a high care load ( $\geq 6$ days per week and helped with all key activities). Therefore, a dementia care team should provide personalized training for the caregivers to increase their knowledge of the disease, their care skills for specific BPSD, and strategies to cope with their own feelings. In addition, referral to appropriate social resources such as caregivers' support groups or respite care is necessary especially for high-risk caregiver populations.

\section{Disclosure}

The authors report no conflicts of interest in this work. 


\section{References}

1. Livingston G, Sommerlad A, Orgeta V, et al. Dementia prevention, intervention, and care. Lancet. 2017;390(10113):2673-2734.

2. Brodaty H. Caregivers and behavioral disturbances: effects and interventions. Int Psychogeriatr. 1996;8(Suppl 3):455-458. doi:10.10 17/S1041610297003840

3. Schulz R, O'Brien AT, Bookwala J, et al. Psychiatric and physical morbidity effects of dementia caregiving: prevalence, correlates, and causes. Gerontologist. 1995;35(6):771-791. doi:10.1093/geront/35.6. 771

4. Mahoney R, Regan C, Katona C, et al. Anxiety and depression in family caregivers of people with Alzheimer disease: the LASER-AD study. Am J Geriatr Psychiatry. 2005;13(9):795-801.

5. Son J, Erno A, Shea DG, et al. The caregiver stress process and health outcomes. J Aging Health. 2007;19(6):871-887. doi:10.1177/ 0898264307308568

6. Schulz R, Beach SR. Caregiving as a risk factor for mortality: the caregiver health effects study. JAMA. 1999;282(23):2215-2219. doi:10.1001/jama.282.23.2215

7. Vitaliano PP, Maiuro RD, Ochs $\mathrm{H}$, et al. A model of burden in caregivers of DAT patients. In: Light E, Lebowitz BD, editors. Alzheimer's Disease Treatment and Family Stress. New York: Hemisphere Publishing Corporation; 1990:267-291.

8. van den Kieboom R, Snaphaan L, Mark L, et al. The trajectory of caregiver burden and risk factors in dementia progression: a systematic review. J Alzheimers Dis. 2020;77(3):1107-1115. doi:10.3233/JAD-200647

9. Chiao CY, Wu HS, Hsiao CY. Caregiver burden for informal caregivers of patients with dementia: a systematic review. Int Nurs Rev. 2015;62(3):340-350. doi:10.1111/inr.12194

10. Cheng ST. Dementia caregiver burden: a research update and critical analysis. Curr Psychiatry Rep. 2017;19(9):64. doi:10.1007/s11920017-0818-2

11. Yan GJ, Wang WF, Jhang KM, et al. Association between patients with dementia and high caregiving burden for caregivers from a medical center in Taiwan. Psychol Res Behav Manag. 2019;12:55-65. doi:10.2147/PRBM.S187676

12. Chen WJ, Wang WF, Liu YH, et al. Using Apriori algorithm to explore the influence of pressure from patients with dementia on caregivers from a medical center in Taiwan. $J$ Qual. 2019;26 (6):395-418. doi:10.6220/joq.201912_26(6).0004

13. Han J, Kamber M. Data Mining: Concepts and Techniques. 2nd ed. New York: Morgan Kaufmann Publishers; 2006.

14. Dichgans M, Leys D. Vascular cognitive impairment. Circ Res. 2017;120(3):573-591. doi:10.1161/CIRCRESAHA.116.308426

15. Wu YT, Lee HY, Norton S, et al. Prevalence studies of dementia in mainland china, Hong Kong and Taiwan: a systematic review and meta-analysis. PLoS One. 2013;8(6):e66252. doi:10.1371/journal. pone. 0066252

16. Ruitenberg A, Ott A, van Swieten JC, et al. Incidence of dementia: does gender make a difference? Neurobiol Aging. 2001;22 (4):575-580. doi:10.1016/S0197-4580(01)00231-7

17. D'Onofrio G, Sancarlo D, Panza F, et al. Neuropsychiatric symptoms and functional status in Alzheimer's disease and vascular dementia patients. Curr Alzheimer Res. 2012;9(6):759-771. doi:10.2174/1567 20512801322582

18. Graff-Radford J. Vascular cognitive impairment. Continuum (Minneap Minn). 2019;25(1):147-164. doi:10.1212/CON.0000000000000684

19. D'Onofrio G, Sancarlo D, Addante F, et al. Caregiver burden characterization in patients with Alzheimer's disease or vascular dementia. Int J Geriatr Psychiatry. 2015;30(9):891-899.

20. Vetter PH, Krauss S, Steiner O, et al. Vascular dementia versus dementia of Alzheimer's type: do they have differential effects on caregivers' burden? J Gerontol B Psychol Sci Soc Sci. 1999;54(2): S93-S98. doi:10.1093/geronb/54B.2.S93
21. Yeager CA, Hyer LA, Hobbs B, et al. Alzheimer's disease and vascular dementia: the complex relationship between diagnosis and caregiver burden. Issues Ment Health Nurs. 2010;31(6):376-384. doi:10.3109/01612840903434589

22. Jhang KM, Wang WF, Chang HF, et al. Care needs of community-residing male patients with vascular cognitive impairment. Neuropsychiatr Dis Treat. 2020;16:2613-2621. doi:10. 2147/NDT.S277303

23. Jhang KM, Chang MC, Lo TZ, et al. Using the Apriori algorithm to classify the care needs of patients with different types of dementia. Patient Prefer Adherence. 2019;13:1899-1912. doi:10.2147/PPA. S223816

24. Sachdev P, Kalaria R, O’Brien J, et al. Diagnostic criteria for vascular cognitive disorders: a VASCOG statement. Alzheimer Dis Assoc Disord. 2014;28(3):206-218. doi:10.1097/WAD.0000000000000034

25. Lewinsohn PM, Seeley JR, Roberts RE, et al. Center for Epidemiologic Studies Depression Scale (CES-D) as a screening instrument for depression among community-residing older adults. Psychol Aging. 1997;12 (2):277-287. doi:10.1037/0882-7974.12.2.277

26. Chong MY, Wilkinson G. Validation of 30- and 12-item versions of the Chinese Health Questionnaire (CHQ) in patients admitted for general health screening. Psychol Med. 1989;19(2):495-505. doi:10.1017/S0033291700012526

27. Chen $\mathrm{HC}, \mathrm{Wu} \mathrm{CH}$, Lee $\mathrm{YJ}$, et al. Validity of the five-item brief symptom rating scale among subjects admitted for general health screening. $J$ Formos Med Assoc. 2005;104(11):824-829. doi:10.6220/joq.201912_26(6).0004

28. Xiong C, Biscardi M, Astell A, et al. Sex and gender differences in caregiving burden experienced by family caregivers of persons with dementia: a systematic review. PLoS One. 2020;15(4):e0231848. doi:10.1371/journal.pone. 0231848

29. Skarupski KA, McCann JJ, Bienias JL, et al. Race differences in emotional adaptation of family caregivers. Aging Ment Health. 2009;13(5):715-724. doi:10.1080/13607860902845582

30. Laks J, Goren A, Duenas H, et al. Caregiving for patients with Alzheimer's disease or dementia and its association with psychiatric and clinical comorbidities and other health outcomes in Brazil. Int J Geriatr Psychiatry. 2016;31(2):176-185. doi:10.1002/gps.4309

31. Goren A, Montgomery W, Kahle-Wrobleski K, et al. Impact of caring for persons with Alzheimer's disease or dementia on caregivers' health outcomes: findings from a community based survey in Japan. BMC Geriatrics. 2016;16(1):122. doi:10.1186/s12877-016-0298-y

32. Wolfs CA, Kessels A, Severens JL, et al. Predictive factors for the objective burden of informal care in people with dementia: a systematic review. Alzheimer Dis Assoc Disord. 2012;26 (3):197-204. doi:10.1097/WAD.0b013e31823a6108

33. Fujihara S, Inoue A, Kubota $\mathrm{K}$, et al. Caregiver burden and work productivity among Japanese working family caregivers of people with dementia. Int J Behav Med. 2019;26(2):125-135. doi:10.1007/ s12529-018-9753-9

34. Sinforiani E, Pasotti C, Chiapella L, et al. Differences between physician and caregiver evaluations in Alzheimer's disease. Funct Neurol. 2010;25(4):205-209.

35. Kim MD, Hong SC, Lee CI, et al. Caregiver burden among caregivers of Koreans with dementia. Gerontology. 2009;55(1):106-113. doi:10.1159/000176300

36. Springate BA, Tremont G. Dimensions of caregiver burden in dementia: impact of demographic, mood, and care recipient variables. Am J Geriatr Psychiatry. 2014;22(3):294-300. doi:10.1016/j.jagp.2012.09.006

37. Franca AB, Gordon AL, Samra R, et al. Symptoms of mood disorders in family carers of older people with dementia who experience caregiver burden: a network approach. Age Ageing. 2020;49 (4):628-633. doi:10.1093/ageing/afaa008

38. Papastavrou E, Kalokerinou A, Papacostas SS, et al. Caring for a relative with dementia: family caregiver burden. $J$ Adv Nurs. 2007;25(5):446-457. doi:10.1111/j.1365-2648.2007.04250.x 
39. Hepburn KW, Lewis M, Sherman CW, et al. The savvy caregiver program: developing and testing a transportable dementia family caregiver training program. Gerontologist. 2003;43(6):908-915. doi:10.1093/geront/43.6.908

40. Reinar LM, Fure B, Kirkehei I, Dahm KT, Landmark B. Effect of day care centers for people with dementia. Report from Kunnskapssenteret no. 21-2011. Oslo: Norwegian Knowledge Centre for the Health Services, 2011.
41. Hsu HC, Chen CF. LTC 2.0: the 2017 reform of home- and community-based long-term care in Taiwan. Health Policy (New York). 2019;123(10):912-916. doi:10.1016/j.healthpol.2019.08.004

\section{Publish your work in this journal}

Risk Management and Healthcare Policy is an international, peerreviewed, open access journal focusing on all aspects of public health, policy, and preventative measures to promote good health and improve morbidity and mortality in the population. The journa welcomes submitted papers covering original research, basic science, clinical \& epidemiological studies, reviews and evaluations, guidelines, expert opinion and commentary, case reports and extended reports. The manuscript management system is completely online and includes a very quick and fair peer-review system, which is all easy to use. Visit http://www.dovepress.com/testimonials.php to read real quotes from published authors.

Submit your manuscript here: https://www.dovepress.com/risk-management-and-healthcare-policy-journal 